3

\title{
Kemiskinan Petani dan Strategi Nafkah Ganda Rumahtangga Pedesaan
}

\author{
Titik Sumarti ${ }^{1}$
}

\section{Ringkasan}

Tinjauan atas fenomena kemiskinan di sektor perkebunan memasuki dimensi baru, sejak adanya krisis ekonomi yang ikut sedikit banyak mempengaruhi sektor ini. Wilayah kajian baru tersebut adalah pola penyesuaian nafkah petani perkebunan skala kecil (plasma) dalam menyiasati krisis ekonomi. Dengan mengkaji dua kasus di Provinsi Riau, diperoleh gambaran strategi adaptasi nafkah yang menarik. Sudi ini menyimpulkan bahwa strategi nafkah ganda menjadi perilaku atau tindakan ekonomi yang menonjol digunakan oleh petani perkebunan miskin di kedua daerah penelitian. Strategi adaptasi nafkah yang diimplementasikan biasanya tetap disesuaikan pada konteks sosio-budaya lokal.

Katakunci: strategi adaptasi nafkah, kemiskinan, perkebunan

\section{Pendahuluan}

Subsektor perkebunan yang didominasi oleh perkebunan rakyat dengan pangsa areal sekitar $80 \%$ telah menunjukkan ketangguhannya dalam menghadapi krisis ekonomi di Indonesia. Bahkan, pada awal krisis ekonomi, perkebunan rakyat mengalami peningkatan kesejahteraan sebagai akibat depresiasi rupiah yang cukup signifikan. Pelajaran yang dapat ditarik dari fenomena tersebut adalah bahwa perkebunan, khususnya perkebunan rakyat, mempunyai potensi sebagai salah satu leading sektor, tidak hanya pada saat ekonomi dalam keadaan booming, tetapi juga ketika terjadi krisis. Beberapa hasil studi menunjukkan bahwa perkebunan rakyat mempunyai peran penting, baik sebagai sumber pertumbuhan maupun untuk perbaikan distribusi pendapatan sekaligus untuk menanggulangi masalah kemiskinan.

Untuk masa mendatang, upaya mempertahankan kontribusi perkebunan rakyat dalam hal pertumbuhan dan pemerataan pendapatan akan menghadapi berbagai masalah. Harga produk perkebunan primer pada tiga tahun terakhir cenderung menurun. Di sisi lain, harga input terus meningkat sehingga keuntungan usaha perkebunan semakin menipis. Produktivitas perkebunan rakyat yang relatif rendah juga merupakan masalah mendasar perkebunan rakyat.

\footnotetext{
${ }^{1}$ Dosen mata kuliah Ekologi Manusia (S1/S2) serta mata kuliah Ekologi Politik pada jenjang S3 Program Studi Sosiologi Pedesaan - Departemen Komunikasi dan Pengembangan Masyarakat IPB. Saat ini mengemban tugas sebagai Sekretaris Pusat merangkap Kepala Divisi Kajian Politik Pertanian dan Pembangunan Pedesaan pada Pusat Studi Pembangunan Pertanian dan Pedesaan IPB.
} 
Di Provinsi Riau, sebagian besar petani di pedesaan pernah melakukan kegiatan berladang, pekebun karet rakyat, dan pencari hasil hutan. Perubahan dalam tata sumberdaya pertanian melalui berkembangnya tanaman ekspor seperti kelapa dalam (kampung), kelapa sawit, dan kopi, telah membawa perubahan kelembagaan. Mengutip Ahmad, Muchtar dkk (2002), kelembagaan lama yang berubah, sementara kelembagaan baru belum berfungsi dengan baik, menyebabkan timbulnya permasalahan sosial maupun ekonomi baik berupa kemiskinan maupun usaha pertanian yang produktivitasnya sulit dikembangkan.

Krisis moneter diikuti dengan krisis ekonomi dan politik (kepercayaan) yang berlangsung pada tahun 1998 di Indonesia telah mengalami proses pemulihan, namun dampak yang terjadi masih relevan untuk didiskusikan. Dampak ekonomi akibat krisis bagi masyarakat di perkotaan maupun perdesaan adalah ledakan pengangguran, daya beli untuk memenuhi kebutuhan hidup (pangan, sandang, papan, pendidikan dan kesehatan) menurun, jumlah penduduk di bawah garis kemiskinan meningkat tajam. Dampak sosial akibat krisis yang bersumber pada krisis moral dan nilai-nilai luhur bangsa adalah disintegrasi sosial, tampak dalam bentuk peningkatan kesenjangan sosial antara golongan kaya dan golongan miskin, dan peningkatan kriminalitas. Sementara pada daerah perkebunan rakyat, dampak ekologi akibat krisis adalah semakin terlantarnya pengelolaan sumberdaya alam (lahan) oleh petani. Hal ini sebagai hasil interaksi dengan kekuatan "supra desa" yang bekerja atas dasar kekuatan pasar, dimana sebagian petani lapisan atas dan pedagang kemudian mendapat keuntungan dan disisi lain sebagian besar lainnya (terutama petani kecil dan buruh petani) menjadi semakin miskin.

Makalah ini bertujuan untuk mengkaji gejala kemiskinan petani kelapa di Indragiri Hilir dan petani kelapa sawit di Kampar selama periode krisis ekonomi akibat tekanan kelembagaan intervensi pasar yang telah membawa perubahan pada kelembagaan ekonomi lokal (patronase dan KUD), dan bagaimana strategi nafkah ganda rumahtangga petani agar dapat meningkatkan taraf hidupnya secara berkelanjutan. Dalam konteks beragam upaya penanggulangan dampak krisis ekonomi, perlu ditelaah bagaimana pemecahan masalah ekonomi, sosial dan lingkungan yang dihadapi petani perkebunan rakyat (dari pendekatan strategi nafkah ganda rumahtangga) serta mencari akar penyebab permasalahan tersebut (dari pendekatan resiko dan dimensi kepentingan). Dimensi kepentingan menjadi dasar perilaku atau tindakan petani dalam berinteraksi mengembangkan strategi nafkah ganda rumahtangga pedesaan.

\section{Metodologi Penelitian}

\subsection{Batasan Pengertian}

Dalam tulisan ini terdapat beberapa konsep yang dipergunakan dan memerlukan batasan pengertian. Konsep tersebut adalah: 
Kemiskinan: adalah kondisi yang bersifat multidimensional, tidak hanya mencakup tingkat pendapatan yang rendah, tetapi juga (a) Kurangnya kesempatan/ akses. Pendapatan yang rendah terkait erat dengan distribusi asset fisik (lahan), sumberdaya manusia, dan asset sosial, serta kesempatan usaha/kerja; (b) Rendahnya kemampuan (pendidikan dan kesehatan); (c) Rendahnya tingkat keamanan (jaminan terhadap resiko dan tekanan ekonomi) baik di tingkat nasional, lokal maupun rumahtangga (individu); (d) Pemberdayaan (kapasitas golongan miskin untuk mengakses dan mempengaruhi kelembagaan dan proses sosial yang membentuk alokasi sumberdaya) (Quibria M.G, 1996)

Pada kasus perkebunan kelapa rakyat di wilayah Indragiri Hilir (inhil) kelembagaan ekonomi lokal (patronase) adalah kelembagaan (pranata sosial) yang mengatur kemudahan petani kelapa mempersiapkan kebutuhannya dalam berusahatani kelapa agar mendapatkan harga jual kopra sebaik-baiknya. Kelembagaan tersebut merupakan kelembagaan asli dari komunitas petani kelapa. Dalam proses tersebut pelaku utamanya selain petani juga ada pemilik modal sekaligus pedagang kopra (tauke).

Sementara itu pada kasus perkebunan kelapa sawit di wilayah Kampar kelembagaan ekonomi lokal (KUD) adalah kelembagaan (pranata sosial) yang mengatur kemudahan petani kelapa sawit mempersiapkan kebutuhannya dalam berusahatani kelapa sawit agar mendapatkan harga jual tandan buah segar kelapa sawit sebaikbaiknya. Kelembagaan tersebut merupakan kelembagaan yang muncul dan exist dalam komunitas petani kelapa sawit. Dalam proses tersebut pelaku utamanya selain petani (anggota KUD) juga ada perusahaan inti (pabrik kelapa sawit) sekaligus pemasar hasil kelapa sawit.

Pola nafkah ganda di pedesaan didefinisikan sebagai "proses-proses dimana rumahtangga membangun suatu kegiatan dan kapabilitas dukungan sosial yang beragam untuk survival/ bertahan hidup dan untuk meningkatkan taraf hidupnya". Mengacu pada Scoones (1998), terdapat tiga strategi nafkah yang berbeda yang dilakukan oleh penduduk pedesaan, yaitu: (1) intensifikasi atau ekstensifikasi pertanian, (2) diversifikasi nafkah, dan (3) migrasi (keluar) berupa perpindahan dengan sukarela/sengaja atau tidak.

Tindakan ekonomi merupakan hasil dari proses yang dilakukan individu dalam proses relasi sosial yang sedang berlangsung. Sebagai sebuah tindakan sosial, maka tindakan ekonomi selalu melibatkan makna dan memperhatikan kekuasaan (sumbangan Weber), dan melekat dalam jaringan hubungan interpersonal antar aktor (sumbangan Granovetter), serta didorong oleh kepentingan sebagai kekuatan mendasar yang didefinisikan secara sosial (sumbangan Swedberg). Mengacu Swedberg (2003), dapat dikemukakan beberapa proposisi: (1) tindakan ekonomi didorong oleh suatu kepentingan sebagai kekuatan yang mendasar, (2) Kepentingan merupakan fenomena sosial yang didefinisikan secara sosial, (3) Kepentingan direalisasikan melalui relasi sosial. 


\subsection{Kerangka Pemikiran}

Ketidakmampuan petani melakukan investasi seringkali bersumber dari perilaku ekonomi petani yang terpinggirkan dalam tatanan komoditi tanaman komersial, yaitu: (1) usaha tani masih berbasis usaha tani keluarga; (2) hasil yang diperoleh minimal karena berlangsung dalam konteks kekurangan modal, lahan, dan tenaga kerja; (3) faktor produksi utama yang dimiliki hanya tenaga kerja. Bagi petani yang hidup dekat batas subsistensi, akibat dari kegagalan atau krisis adalah terusiknya jaminan subsistensi, sehingga mereka lebih mengutamakan apa yang dianggap aman dan dapat diandalkan daripada keuntungan yang dapat diperoleh dalam jangka panjang (Scott, 1989).

Pada kasus perkebunan kelapa rakyat, kelembagaan ekonomi lokal (patronase) yang mengatur hubungan antara petani dan pemilik modal sekaligus pedagang (tauke) mengembangkan tatanan yang berorientasi pada prinsip pertukaran (resiprositas) balas budi dan tata nilai subsistensi. Hal ini berarti petani dapat mendistribusikan resikonya kepada tauke, yang berfungsi sebagai asuransi sosial bagi petani. Sementara itu pada kasus perkebunan kelapa sawit, kelembagaan ekonomi yang ada yaitu KUD dan perusahaan inti, mengatur hubungan antara petani dan pemilik modal sekaligus pemasar mengembangkan tatanan yang berorientasi pada prinsip ekonomi (pasar). Hal ini berarti petani mendapat kesulitan untuk mendistribusikan resikonya pada kelembagaan.

Fenomena yang tampak (pada kedua kasus tersebut) adalah manakala tekanan intervensi pasar menguat, maka yang terjadi adalah perubahan kelembagaan ekonomi lokal yang berakibat pada menurunnya kesejahteraan ekonomi petani dan meningkatnya kesenjangan antar lapisan. Kelembagaan intervensi pasar, mengembangkan tatanan yang berorientasi pada prinsip pertukaran pasar (keuntungan semata). Proses pertukaran tipe ini dalam teori pertukaran sosial Burns, dkk (1987) disebut sebagai pertukaran sosial yang berorientasi terhadap kepentingan pribadi (orientasi aktor secara tunggal pada manfaat dan keuntungan sendiri) dan sekaligus terhadap kepentingan orang lain (kerjasama). Pabrik minyak kelapa sebagai kelembagaan intervensi pasar tak mampu secara langsung (atau bahkan bekerjasama dengan tauke) melakukan intervensi pasar, dan sistem patronase yang telah mengakar, sementara tidak ada kontrol yang signifikan dari pemerintah, telah mengkondisikan aktivitas ekonomi pemasaran kelapa sedemikian rupa sehingga petani semakin tak berdaya.

Kondisi ketidakberdayaan petani kelapa yang diperparah oleh fluktuasi (naik turunnya) harga kopra di tingkat petani, yang pada gilirannya saling berhubungan dengan beragam faktor pengelolaan (seperti penggunaan tenaga kerja, pengadaan modal, bahan, alat, pemasaran dan pengembangan usaha) telah memperburuk kondisi pengelolaan perkebunan kelapa rakyat. Hal ini telah mendorong petani untuk mengembangkan strategi nafkah rumahtangga agar dapat bertahan hidup dan meningkatkan taraf hidupnya dengan beragam dimensi kepentingan didalamnya. 
Rasa keadilan yang terusik, karena tauke melanggar cadangan subsistensi petani, telah memunculkan perlawanan dari petani (sikap dan perilaku acuh tak acuh). Hal ini mengindikasikan bahwa dalam rangka pemilihan strategi nafkah rumahtangga untuk meningkatkan taraf hidupnya, ternyata kepentingan sosial (jaminan rasa aman) memegang peranan penting. Selain itu proses-proses kolektivitas lebih penting daripada proses-proses individu dalam membentuk pilihan maupun keputusan. Lingkungan transaksi yang diorganisasi oleh pasar banyak ditetapkan oleh kapsul sosial. Tidak ada transaksi diantara mereka yang setara, melainkan ditentukan oleh kepentingan kekuasaan (Etzioni, 1992; Swedberg, 1998).

\subsection{Pendekatan Lapang}

Hasil penelitian ini merupakan bagian dari penelitian Studi Produksi Perkebunan Rakyat dan Penanggulangan Kemiskinan yang dilakukan oleh Pusat Penelitian dan Pengembangan Perkebunan bekerjasama dengan World Bank tahun 2000. Lokasi yang dipilih untuk perkebunan kelapa rakyat adalah kecamatan Mandah, kabupaten Indragiri Hilir, dan untuk perkebunan kelapa sawit rakyat adalah Perkebunan Inti Rakyat-Transmigrasi (PIR-Trans) kecamatan Tapung, Kabupaten Kampar. Pengumpulan data dilakukan dengan beragam teknik, mencakup: diskusi dengan tokoh-tokoh petani beragam status, diskusi kelompok dengan anggota kelompok dan anggota organisasi, wawancara mendalam dengan rumahtangga petani sukses/mampu dan petani belum sukses/ miskin, wawancara dengan pengurus kelompok dan pengurus organisasi, serta informan lainnya: pedagang, pengusaha, penyuluh, tokoh formal dan informal desa. Validitas data dilakukan dengan menggunakan teknik triangulasi melalui beragam subyek dan informan, teknik wawancara dan pengamatan.

\section{Hasil Penelitian Dan Pembahasan}

\subsection{Pengelolaan Perkebunan Rakyat dan Gejala Kemiskinan}

Kemunduran pengelolaan perkebunan rakyat dipengaruhi oleh kekuatan luar (kondisi pasar dunia, harga-harga yang selalu berubah diluar kendalinya, kepentingan politik pemerintah dan perusahaan swasta, serta ketergantungan terhadap pihak luar). Pada gilirannya mempengaruhi/saling terkait dengan beragam faktor penentu pengelolaan perkebunan rakyat (mencakup: penggunaan tenaga kerja, pengadaan modal, pengadaan bahan dan alat, pengadaan teknologi dan informasi, pemasaran dan pengembangan usaha).

Pada kasus perkebunan kelapa di wilayah Inhil, kondisi turunnya harga, terutama mengakibatkan ketidakmampuan petani dalam: (a) menggunakan tenaga kerja upahan (sedangkan tenaga kerja keluarga memiliki keterbatasan waktu, karena harus melakukan beragam nafkah ganda: menjadi buruh perusahaan misalnya), (b) menambah permodalan, bahkan untuk membayar hutang ke tauke (bahkan sampai pada posisi "menutup buku" dulu), dan (c) membeli pupuk dan peralatan. Ketiga

\footnotetext{
${ }^{2}$ Kebijaksanaan tutup buku (istilah setempat) ini dilakukan oleh tauke pada saat harga kopra turun (rendah) yang dimaksudkan untuk "membantu" petani pekebun. Caranya adalah untuk sementara waktu hutang
} 
faktor tersebut pada akhirnya menurunkan kuantitas dan kualitas hasil produksi dan (d) membuat petani semakin tergantung pada tauke dan pabrik minyak kelapa dalam hal pemasaran, karena berada pada posisi tak berdaya dalam penentuan harga, serta (e) mundurnya usaha, baik karena penjualan kebun kelapa, maupun karena terlantarnya lahan kebun (lihat lampiran 1).

Semakin buruk atau mundurnya pengelolaan perkebunan kelapa rakyat, pada akhirnya berdampak pada penurunan kesejahteraan ekonomi petani. ${ }^{3}$ Gejala kemiskinan dan perilaku ekonomi petani yang terpinggirkan dalam tatanan komoditi tanaman komersial merupakan fenomena nyata yang berlangsung pada petani kelapa di wilayah Indragiri Hilir. Namun sumber dari kemiskinan petani bukanlah krisis itu sendiri, melainkan pada penguasaan asset/modal dan tatanan kelembagaan ekonomi lokal (patronase). Menguatnya ketimpangan dalam penguasaan asset/modal antar lapisan ditandai dengan ciri-ciri petani miskin dan petani sukses menurut ukuran masyarakat setempat. (lihat lampiran 2)

Selanjutnya pada kasus PIR-Trans kelapa sawit di wilayah Kampar, dinamika pengelolaan PIR-Trans kelapa sawit lima tahun terakhir lebih terlihat setelah dilakukan konversi. ${ }^{4}$ Kondisi pengelolaan perkebunan kelapa sawit cenderung semakin membaik.

Asumsi yang digunakan adalah bahwa keberhasilan usahatani sangat ditentukan oleh pengalaman pribadi seorang petani. Prestasi ekonomi seorang petani akan optimum apabila seorang petani bertindak secara leluasa sesuai dengan pengalaman usahataninya. Bila petani bekerja pada perusahaan inti kelapa sawit dan dengan birokrasi dan aturan formal, maka mereka cenderung tidak dapat bekerja secara leluasa untuk menerapkan pengetahuan dari pengalaman pribadinya sehingga tidak jarang produktivitas mereka akan merosot.

Namun dalam kasus PIR-Trans kelapa sawit di wilayah Kampar ${ }^{5}$ yang terjadi adalah bahwa latar belakang para petani relatif beragam. Artinya tidak semua petani telah memiliki pengalaman pribadi sebagai petani, sehingga pengalaman menjadi buruh perkebunan inti sebelum masa konversi merupakan proses pengalaman berharga untuk meningkatkan kemampuan petani pekebun dalam menerapkan teknologi pengelolaan kebun.

Tampaknya penjelasan secara sosiologis lebih tepat digunakan, bahwa ketika posisi sebagai petani telah meningkat, yaitu setelah masa konversi, dimana

petani pekebun kelapa pada waktu yang lalu (lama) tidak perlu dibayar dahulu. Namun setelah tutup buku petani pekebun tidak boleh berhutang lagi dengan tauke, kecuali hutang yang lama sudah lunas.

3 “Agar petani tidak menjerit kelaparan, maka seharusnya harga sepikul kopra sebanding dengan kebutuhan beras per bulan. Kopra saat ini per pikul (100 kg) hanya dihargai sekitar Rp 80.000,- sampai Rp 85.000,-, sedangkan harga beras sudah mencapai Rp 3000,- - Rp 3500,-/kg. Dalam tiga bulan (sekali menjual/panen) paling-paling hanya tiga pikul kopra, padahal pendapatan minimal yang dibutuhkan petani (dengan dua anak) untuk makan sehari-hari (diluar biaya sekolah dan biaya sosial lainnya) adalah sekitar Rp 500.000,per bulan."

${ }^{4}$ Masa konversi adalah masa serah terima kebun plasma dari pihak inti/perusahaan kepada petani plasma

${ }^{5}$ Desa Tapung Makmur Kecamatan Tapung 
dahulunya sebagai buruh, maka saat ini ia sudah menjadi pemilik kebun kelapa sawit. Dengan kata lain, saat ini ia sudah menjadi manajer dan tentu akan berusaha mengelola kebunnya secara lebih baik.

Pengelolaan kebun juga cukup dipengaruhi oleh kondisi kekuatan luar. Kekuatan luar seperti pasar dunia, terutama naik turunnya harga sukup mempengaruhi perekonomian para petani PIR-Trans kelapa sawit. Pada saat krisis moneter, harga kelapa sawit/tandan buah segar membaik, namun pada saat ini harga tandan buah segar justru lebih rendah daripada masa sebelum krisis. $^{6}$ Meskipun demikian, perubahan harga tandan buah segar tersebut tampak tidak cukup mempengaruhi pola pengelolaan perkebunan rakyat. Hal ini karena adanya beragam faktor yang menentukan pengelolaan perkebunan seperti (1) penggunaan pupuk; (2) permodalan; (3) teknologi dan informasi; (4) pemasaran masih banyak mendapat bantuan dari inti melalui koperasi, sedangkan penggunaan tenaga kerja dalam hal tertentu ${ }^{7}$ masih dilakukan secara bersama dengan anggota kelompok lainnya. Hal ini berarti bahwa resiko atas harga terhadap pengelolaan perkebunan merupakan resiko bersama demi tercapai rasa aman dalam usaha bersama.

Perilaku petani dalam mengelola perkebunan rakyat cenderung bermotif tindakan rasional instrumental, yaitu tindakan yang didasarkan atas nilai-nilai untung rugi secara ekonomi. Dalam kondisi tekanan ekonomi, maka akan lebih menguntungkan jika mengurangi resiko daripada kalau semakin bergantung pada koperasi dan pabrik kelapa sawit. Kemajuan pengelolan perkebunan ini dapat dibuktikan dari kemampuan petani pekebun dalam pengembangan usahanya.

Di satu sisi telah terjadi kemajuan dalam pengelolaan perkebunan rakyat, namun disisi lain sesungguhnya sedang terjadi proses menguatnya ketergantungan dari petani perkebunan terhadap koperasi dan pabrik kelapa sawit/perkebunan inti dihampir semua bidang pengelolaan kebun, termasuk transportasi, kecuali dalam penggunaan tenaga kerja.

Artinya adalah petani semakin tidak otonom dalam mengembangkan usahanya. Mampukan petani dalam kondisi demikian meningkatkan keuntungan usaha pribadinya? Atau yang terjadi adalah petani telah menjadi "buruh" bagi keuntungan koperasi dan pabrik kelapa sawit sebagai perusahaan bisnis?

\subsection{Tatanan Kelembagaan Ekonomi Lokal (Patronase, KUD) : Etika Subsistensi Masihkah Menjadi Tuntutan Moral?}

Pada kasus perkebunan kelapa di wilayah Inhil, kelembagaan tradisional permodalan dan pemasaran yang masih exist adalah tauke (pelepas uang, pedagang pengumpul). Sedangkan kelembagaan modern yang muncul dan sering diasosiasikan dengan

\footnotetext{
${ }^{6}$ pada saat ini harga tandan buah segar kelapa sawit hanya sekitar Rp 527,-

${ }^{7}$ proses penimbangan masih dilakukan secara bergantian atau tolong menolong
} 
tauke karena peranannya menggantikan posisi tauke adalah koperasi dan perusahaan besar (pabrik minyak kelapa/goreng).

Keberadaan tauke masih diperlukan petani kelapa, karena lembaga pemasaran ini sekaligus berfungsi sebagai lembaga permodalan/perkreditan yang banyak didatangi petani dibandingkan lembaga perbankan. ${ }^{8}$ Lembaga pemasaran yang lebih besar sebagai penampung para tauke adalah pabrik pengolahan kopra (PT Sambu). ${ }^{9}$ Keberadaan pabrik ini cenderung bersifat monopoli ${ }^{10}$ dan berperan sebagai tauke terbesar (lembaga pemasaran sekaligus lembaga perkreditan) bagi tauke-tauke besar. Oleh sebab itu, perubahan harga kopra selain ditentukan oleh kekuatan eksternal (pasar dunia), juga dimainkan ${ }^{11}$ oleh pabrik pengolahan kopra sebagai pemegang kendali utama.

Kelembagaan yang baru muncul, seperti koperasi ${ }^{12}$ bertujuan meningkatkan kesejahteraan petani yang relatif masih rendah. Namun keberadaan kelembagaan koperasi ini tampaknya belum efektif, apalagi untuk dapat bersaing dengan tauke. Kendala utama yang dihadapi adalah belum mampu mengakses ${ }^{13}$ lembaga permodalan yang ada. Demikian pula manfaat yang dirasakan bagi petani masih sebatas pada manfaat sosial (petani semakin intens berhubungan secara sosial) dan belum mendapatkan manfaat ekonomi (membantu meningkatkan perekonomian anggota).

Tatanan kelembagaan ekonomi lokal membangun aturan main berdasar "kesepakatan" antara petani dengan tauke. Namun pada kenyataannya petani tidak pernah bisa terlibat dalam proses penentuan harga. ${ }^{14}$ Tidak ada keterbukaan dalam penentuan dan penetapan harga. Petani pada umumnya hanya menerima harga yang telah ditetapkan oleh tauke atau PT. Sambu. Petani tidak pernah tahu berapa sebenarnya harga resmi yang sedang berlaku. Petani hanya mendengar dan tahu dari tauke saat menjual kopranya. Padahal harga kopra di tiap desa terdapat

\footnotetext{
8 "Umumnya tauke masih diperlukan oleh petani kelapa di desa Igal saat ini, karena siapa lagi yang mau membeli kopra dan meminjami petani modal dan pemenuhan kebutuhan sehari-hari. Tak ada petani yang pinjam ke bank, lebih baik pinjam ke tauke tanpa bunga ( $3-6$ bulan) dan bukan sistem ijon".

${ }^{9}$ PT. Sambu merupakan perusahaan swasta yang menampung dan mengolah produksi kelapa rakyat. Di kabupaten Indragiri Hilir hanya perusahaan ini yang beroperasi dan berada di dua tempat, yaitu PT. Sambu yang berada di Pulau Sambu menampung kopra sedangkan yang di Kuala Enok menampung kelapa butiran. Umumnya kelapa hasil produksi masyarakat desa Igal dijual ke Pulau Sambu.

${ }^{10} \mathrm{Di}$ kabupaten Indragiri Hilir hanya ada satu perusahaan yang menampung kelapa rakyat yaitu PT. Sambu.

${ }^{11}$ Seringkali terjadi permainan harga hasil kebun. Jika petani banyak menjual hasil dalam bentuk kopra, maka harga kopra akan turun dan kelapa butiran naik. Demikian pula sebaliknya, jika petani banyak menjual kelapa butiran, maka harganya akan turun dan harga kopra naik.

${ }^{12}$ Koperasi Karya Mekar di Desa Ular Lidi, Igal - Inhil berdiri pada tanggal 19 Mei 1999. Jumlah anggota yang aktif saat ini adalah 25 orang. Kedudukan koperasi di parit Ular Lidi. Ketua Koperasi Mansur, SE; sekretaris Maskandar dan Bendahara H. Herman.

13 Berdasarkan penuturan salah seorang pengurus, sebenarnya beliau mempunyai jaringan (relasi) di Tembilahan, beberapa orang elite pemerintahan merupakan temannya sewaktu kuliah di S1 dahulu.

14 "Petani tidak pernah bisa (sulit) ikut terlibat dalam proses menentukan harga, tidak ada proses tawar menawar dalam menentukan harga. Harga kopra yang dijual petani sudah ditentukan langsung oleh Tauke $^{14}$ berdasarkan harga yang telah ditetapkan sebelumnya oleh PT. Sambu sebagai perusahaan besar yang membeli hasil kopra (hampir seluruh hasil kopra di Inhil bermuara di PT. Sambu).
} 
perbedaan. Petani hanya bisa mendengar dan mengeluh dengan adanya perbedaan harga ini dan tidak tahu mengapa terjadi demikian. ${ }^{15}$

Tatanan kelembagaan ekonomi lokal (patronase) telah menciptakan mekanisme sedemikian rupa sehingga tekanan ekonomi tidak melanggar subsistensi petani. Tauke memberi asuransi sosial, dimana resiko ekonomi petani didistribusikan kepada tauke. Meskipun untuk ini, petani harus menanggung hutang yang cukup banyak kepada tauke, yang penting kebutuhan jangka pendek terpenuhi. Namun disisi lain sesungguhnya mekanisme tersebut tak mampu memberi peluang mobilitas sosial bagi petani atau peningkatan kesejahteraan mereka manakala ada peluang ekonomi baru muncul. Hubungan yang demikian itu pada akhirnya merugikan petani. Petani sudah tidak mau lagi terlibat dalam proses jual beli (misalnya melakukan pengawasan terhadap proses penimbangan, penentuan harga dll). ${ }^{16}$

Rasa ketidakadilan dengan demikian dimaknai bukan sebagai terusiknya cadangan subsistensi petani, namun sebagai tidak adanya akses petani untuk meningkatkan status atau kesejahteraan melalui penguasaan asset/modal. Hal ini ditunjukkan dengan adanya upaya petani untuk melepaskan diri dari tauke. Namun jika hal ini terjadi, maka petani tersebut akan mendapat sebutan dengan "liar". ${ }^{17}$ (lihat lampiran 3)

Kemudian pada kasus PIR-Trans Kelapa Sawit di wilayah Kampar, kelembagaan pengadaan sarana produksi dan pemasaran dalam usaha perkebunan kelapa sawit yang masih exist adalah $\mathrm{KUD}^{18}$ (menyediakan/memfasilitasi penyediaan sarana produksi dan pemasarana hasil). Kelembagaan tersebut dapat dikatakan sebagai kelembagaan modern.

${ }^{15}$ Diskusi dengan berbagai informan (seperti wali desa, tauke, ketua BPD) dan dari hasil wawancara yang dilakukan di rumah wali desa Igal perbedaan ini disebabkan oleh kualitas salai kopra, upah buruh angkut atau kualitas kelapa itu sendiri. Umumnya petani hanya menyalai (asap) kelapa satu kali (kurang kering sehingga kadar air tinggi), di desa Igal untuk menurunkan kopra dari perahu ke dalam gudang milik tauke mengunakan tenaga buruh angkut (spesialisasi), sedangkan di desa lain (seperti Bakau Aceh dan daerah Semboang) hanya menggunakan tenaga penjaga gudang. Upah buruh umumnya oleh tauke diambil/dipotong dari hasil kopra ini. Kelapa yang dihasilkan dari desa Igal umumnya buahnya "lemas" (meliuk) dan tidak keras dan kadar airnya tinggi. Kemungkinan hal ini karena kondisi tanah yang bergambut dan kurang padat, tidak seperti kondisi tanah di daerah Tanah Merah yang lebih padat.

16 "Saat proses penimbangan kopra (di tempat tauke) petani jarang bahkan cenderung tidak mau mengikut atau pun mengawasi jalannya penimbangan tersebut (dan jika mengawasi hanya sebagai basa basi --purapura--). Sehingga pada umumnya (kemungkinan besar) berbagai kecurangan dalam penimbangan (celat sekilo dua kilo) yang dilakukan oleh tauke sering diabaikan oleh petani. Hal seperti ini (celat) sebenarnya sudah menjadi rahasia umum dikalangan petani kopra, namun petani "tak kuasa" untuk bertanya apalagi memperbaikinya/ merobah. Selain itu jumlah potongan terhadap berat kopra juga dianggap merugikan petani (petani sering menyebutnya potongan goni. Seolah-olah petani seperti mengabaikan kecurangan ini, karena petani sudah merasa banyak "berhutang budi" pada tauke".

${ }^{17}$ Untuk mengatasi klien liar ini biasanya dilakukan rundingan/negsosiasi (cara kekeluargaaan), khususnya dengan hutang yang telah diterima petani. Hutang harus dibayar lunas. Jika petani sudah melunasi hutangnya, maka tauke tidak akan mau menjadikannya anak buah (klien) lagi. Hal ini dilakukan karena klien dianggap tidak menghormati tauke dan tidak jujur.

${ }^{18}$ Koperasi Unit Desa Lestari Jaya berdiri tahun 1995, sebelum konversi, dipersiapkan oleh Ka UPT, satu paket dengan pembentukan desa persiapan (catatan: “dikejar target”). Dari semula $400 \mathrm{KK}$, tidak semua menjadi anggota koperasi Lestari Jaya. Pada tahun 1996 telah memiliki Badan Hukum, dan 1997 KUD mulai aktif berkegiatan seiring dengan kebun sawit plasma yang juga memasuki masa sudah konversi. 
Selain KUD, berkembang gejala munculnya pembeli (tauke) sawit dari lahan pekarangan. ${ }^{19}$ Keberadaan tauke pembeli buah dari lahan pekarangan ini diperlukan oleh petani, karena mereka mau membeli dan memasarkan buah sawit, meskipun dalam jumlah yang seditkit. Selain itu, para tauke juga berfungsi sebagai lembaga permodalan (pinjam uang) yang bersedia langsung mendatangi petani.

Sedangkan kelembagaan pemasaran yang lebih besar sebagai penampung, baik dari KUD dan tauke adalah pabrik kelapa sawit milik perusahaan inti. ${ }^{20}$ Keberadaan pabrik ini cenderung bersifat memonopoli ${ }^{21}$ dan berperan sebagai tauke terbesar (lembaga pemasaran sekaligus lembaga pengadaan sarana produksi) bagi para petani plasma. Oleh sebab itu, perubahan harga kopra selain ditentukan oleh kekuatan eksternal (pasar dunia), diduga juga "dimainkan" oleh konglomerasi pabrik sebagai pemegang kendali utama.

Dalam hal pengorganisasian petani, kelembagaan atau organisasi yang baru muncul adalah kelompok kerja yang dibentuk atas kesadaran para warga (kelompok partisipatif). Dalam kasus PIR-Trans kelapa sawit di desa Tapung Makmur, penumbuhan kelompok tersebut sudah mengarah kepada pembentukan yang berdasarkan atas ikatan pekerjaan atau profesional seperti pada kasus kelompok Tunas Harapan. ${ }^{22}$ Pembentukan kelompok sudah diarahkan untuk mencapai tujuan kesejahteraan bersama.

Keberadaan kelembagaan atau organisasi ini tampaknya bisa lebih efektif, untuk meningkatkan produktivitas petani. Setidaknya potensi sosial yang dapat dikembangkan dari kelompok kerja profesional adalah nilai-nilai solidaritas kelompok dan mekanisme pengelolaan konflik dalam kelompok.

Meskipun saat ini KUD telah ada, namun lembaga ini belum mampu memfasilitasi petani untuk meningkatkan modal. Kendala utama yang dihadapi, baik oleh KUD maupun petani adalah belum mampu mengakses lembaga permodalan yang ada. Akibatnya para petani pun belum merasakan manfaat sosial dari lembaga yang ada dan belum mendapatkan manfaat ekonomi (membantu meningkatkan perekonomian anggota).

Tatanan ekonomi perkebunan kelapa sawit membangun aturan main berdasar "kesepakatan" antara berbagai pihak yang terlibat (petani, KUD, perusahaan dan pemerintah). Namun pada kenyataannya petani tidak pernah bisa melakukan proses penentuan harga. ${ }^{23}$ Tidak ada keterbukaan dalam penentuan dan penetapan

\footnotetext{
${ }^{19}$ Petani setempat menyebutnya buah PK

${ }^{20} \mathrm{PT}$. Buana Wira Lestari

${ }^{21}$ Di kabupaten Indragiri Hilir hanya ada satu perusahaan yang menampung kelapa rakyat yaitu PT. Sambu.

${ }^{22}$ Kelompok ini terbentuk pada tahun 1995 dengan anggota sebanyak 20 orang. Tujuannya adalah untuk mempermudah pengelolaan (pembayaran kredit dan gaji), maka setiap transmigran harus memiliki kelompok dan akhirnya terbentuklah kelompok-kelompok sehamparan lahan sawit (1 blok hamparan lahan kelapa sawit yaitu $40 \mathrm{ha}$ ). Berdasarkan aturan tersebut pula, maka kelompok tidak bisa menambah jumlah anggota

23 "Petani tidak pernah bisa (sulit) ikut terlibat dalam proses menentukan harga, tidak ada proses tawar menawar dalam menentukan harga. Harga TBS yang dijual petani sudah ditentukan langsung dari pabrik berdasarkan harga yang telah ditetapkan sebelumnya oleh perusahaan.
} 
harga. Petani pada umumnya hanya menerima harga yang telah ditetapkan oleh perusahaan berdasarkan "kesepakatan" tersebut. Pada akhirnya petani tidak pernah tahu berapa sebenarnya harga resmi yang sedang berlaku. Petani hanya mendengar dan tahu dari KUD/perusahaan saat menjual TBS.

Bahkan terdapat kecenderungan bahwa KUD lebih merupakan penguatan kelembagaan ${ }^{24}$ bagi perusahaan inti (pabrik kelapa sawit) daripada membela kepentingan petani pekebun dalam rangka pengembangan usaha individunya. Meskipun demikian, karena tidak ada pilihan alternatif lain dalam pemasaran ${ }^{25}$ maupun masih adanya permainan politik antara pemerintah dan swasta, ${ }^{26}$ maka pilihan terbaik petani adalah tetap atau semakin bergantung kepada perusahaan inti. $^{27}$

Tatanan kelembagaan ekonomi dan sistem perkebunan telah menciptakan mekanisme sedemikian rupa sehingga tekanan ekonomi tidak melanggar subsistensi petani. KUD selama ini hanya mampu memberikan supply kebutuhan sehari-hari kepada petani. Meskipun para petani mengambilnya dengan cara berhutang dan dibayar saat panen tiba. Selain itu, sistem perkebunan juga mampu memberikan berbagai lapangan pekerjaan (dodos, nebas pelepah, membuat piringan/membersihkan rumput dsb) yang bisa memberikan pendapatan tambahan bagi para petani. Meskipun untuk ini, petani harus menanggung hutang yang cukup banyak dan kerja ekstra, namun yang penting kebutuhan jangka pendek mereka terpenuhi.

Tetapi, disisi lain sesungguhnya mekanisme tersebut tidak mampu memberi peluang mobilitas sosial bagi petani atau peningkatan kesejahteraan mereka manakala ada peluang ekonomi baru muncul. Hubungan yang demikian itu pada akhirnya merugikan petani. Petani saat ini lebih banyak pasrah dan berusaha memenuhi kebutuhan hidupnya dengan berbagai usaha seperti menanam pekarangan dengan berbagai tanaman yang produktif.

${ }^{24}$ selama ini KUD hanya berperan sebagai perantara penjualan TBS ke PKS dan belum bisa membantu meningkatkan daya tawar menawar

${ }^{25}$ TBS petani plasma selama ini hanya dapat dijual kepada perusahaan inti (PKS)

${ }^{26}$ Pengalaman petani yang pernah ikut dalam tim penentuan harga mengatakan bahwa PT. Sinar Mas mampu membeli TBS dengan harga tinggi. Namun setelah dimusyawarahkan bersama tim (diambil harga ratarata), harga yang ditawarkan oleh PT Sinar Mas tersebut tidak dapat diterapkan. Informan ini menduga bahwa perbedaan harga tersebut (selisih) dibagi sebagai "suap" untuk tim dan pemda.

${ }^{27}$ Petani penggarap tetap optimis, bahwa setelah lunas kredit mereka akan tetap menjual ke PT Sinar Mas, dengan alasan:

- Ketergantungan pada fasilitas jalan yang disediakan oleh pabrik dan sarana transportasi oleh KUD, selama ini transportasi masih dirasakan mahal dan pihak inti mampu menyediakan semuannya.

- Petani penggarap merasakan bahwa harga beli TBS yang diberlakukan oleh perusahaan inti tidak merugikan petani (malahan petani menganggap harga beli TBS PT. Sinar Mas lebih tinggi dibanding dengan perusahaan lain).

- Selama ini sarana produksi (seperti pupuk dan obat-obatan) dalam penyediaannya masih melibatkan perusahaan (yg melakukan order perusahaan inti) meskipun kemudian disalurkan kepada KUD (KUD belum mampu melakukan order secara langsung dengan perusahaan punyuplai saprotan.

- Dalam menentukan (uji) kadar rendemen, petani penggarap tidak mengetahui secara teknis bagaimana proses uji tersebut terjadi. Petani saat ini hanya mengandalkan hasil uji laboratorium yang dilakukan oleh pabrik. 
Rasa ketidakadilan dengan demikian dimaknai bukan sebagai terusiknya cadangan subsistensi petani, namun sebagai tidak adanya akses petani untuk meningkatkan status atau kesejahteraan melalui penguasaan asset/modal. Hal ini tampak dari sikap dan perilaku petani yang pasif terhadap semua kegiatan KUD (misalnya tidak mau mengikuti acara rapat anggota, iuran dan sebagainya).

\subsection{Dinamika Kesejahteraan Ekonomi dan Strategi Nafkah Ganda Rumahtangga Petani}

Dalam mengelola perkebunan rakyat sebagai suatu usaha bisnis, sejauhmana usaha tersebut telah dapat meningkatkan kesejahteraan ekonomi petani? Bagaimanakah dinamika kesejahteraan petani perkebunan rakyat disaat krisis? Bagaimana pula strategi nafkah ganda yang dilakukan petani pekebun dalam bertahan hidup dan meningkatkan taraf hidupnya? Apa kepentingan yang mendasari petani dalam mengembangkan strategi nafkahnya?

Pada kasus perkebunan kelapa di wilayah Inhil, pengelolaan perkebunan rakyat di wilayah Indragiri Hilir relatif dapat meningkatkan kesejahteraan ekonomi masyarakat. Hal ini dapat dibuktikan dengan semakin luasnya lahan kebun (areal kebun kelapa yang dimiliki petani pekebun semakin luas), semakin banyaknya petani pemilik kebun, peningkatan pendidikan anak-anak. Masa kejayaan kesejahteraan ekonomi dicapai pada masa krisis (era pemerintahan presiden $\mathrm{Habibie}^{28}$ ). Faktor yang menentukan kesejahteraan petani pekebun adalah membaiknya harga kopra di tingkat petani yang berimplikasi pada terciptanya beberapa peluang kerja dalam usaha kebun (pemeliharaan kebun).

Pada masa tiga tahun pasca krisis terjadi proses penurunan tingkat kesejahteraan ekonomi masyarakat akibat dari turunnya harga kopra di tingkat petani, sehingga berdampak pada munculnya kemiskinan pada masyarakat petani. Menurut ukuran masyarakat setempat, fenomena kemiskinan dan strategi nafkah yang dilakukan rumahtangga petani dapat dilihat dari: (lampiran 2)

"Ciri-ciri Ekonomi: Tanaman belum menghasilkan; Lahan kebun kelapa relatif sempit (kurang dari 200 kelapa); Diversifikasi nafkah dalam rangka bertahan hidup: beragam pekerjaan srabutan (bhs. lokal: rames) dengan upah kecil (contoh: mencari kayu di hutan, menangkap ikan); Hanya satu anggota rumahtangga/keluarga yang bekerja, yaitu Kepala Keluarga;Tak mampu menanggulangi resiko gagal usaha kebun".

"Ciri-ciri Sosial: Status relatif tetap, bahkan menurun (contoh: menjadi pencari kayu di hutan atau nggesek atau mencari kerja di luar); Relatif tak punya hubungan/jaringan kerja (hanya dengan tauke/pedagang kayu); Tindakan

\footnotetext{
${ }^{28}$ Pada saat itu banyak petani, khususnya di desa Igal yang mwenunaikan ibadah haji (ukuran untuk petani yang mampu/kaya), menikahkan anak, dan membangun rumah serta melunasi hutang.
} 
cenderung afektif, (kasus Sn): sebagai respons terhadap kemampuan penghasilan dari usaha tani kelapa, yang sering tak cukup untuk memenuhi kebutuhan hidup sehari-hari; Ketidakmampuan untuk menentukan harga, karena ketergantungan dengan tauke (kasus Sn, dengan tauke/pedagang kayu), melalui hutang untuk mencukupi kebutuhan sehari-hari”.

Sedangkan ukuran sukses menurut masyarakat setempat adalah :

"Ciri ekonomi: Tanaman sudah menghasilkan; Lahan kebun kelapa bertambah luas (kasus H. Herman, lebih dari 750 pohon kelapa); Diversifikasi usaha dalam rangka akumulasi modal; Anggota rumahtangga/ keluarga bekerja dalam usaha yang dikembangkan oleh Kepala Keluarga (kaderisasi); Mampu menanggulangi resiko kegagalan usaha kebun, karena ada jaminan dari pekerjaan lain (kasus H. Herman, berdagang)”.

"Ciri sosial:

Status meningkat, dengan cara naik haji; Memiliki hubungan yang luas (kasus H. Herman, dengan petani pembuat sagu dan gula merah, dengan tauke); Tindakan cenderung mengarah rasionalitas nilai, berbasiskan kepercayaan/ budaya dan agama (kasus $H$. Herman, "cina surga dunia, melayu surga akhirat"); Mampu menentukan harga, dalam hubungan dengan pengrajin gula dan sagu; Serta mendapatkan kepercayaan dari tauke".

Kemudian pada kasus PIR-Trans Kelapa Sawit di Wilayah Kampar, pada saat krisis berlangsung peningkatan kesejahteraan ekonomi juga dialami oleh petani pekebun PIR-Trans kelapa sawit yang sudah konversi. ${ }^{29}$ Kondisi kesejahteraan ekonomi dari petani pekebun dapat dilihat dari kemampuan memperluas usaha/lahan kebun; naik haji; peningkatan pendidikan bagi anak-anaknya; akumulasi modal melalui diversifikasi usaha.

Namun peningkatan kesejahteraan ekonomi tidak berlangsung lama, selama dua tahun pasca krisis harga tandan buah segar semakin merosot seiring menguatnya nilai rupiah. Dalam kondisi demikian cenderung terjadi penurunan kesejahteraan yang mengarah pada kemiskinan petani pekebun PIR-Trans. Fenomena kondisi kemiskinan menurut persepsi komunitas PIRTrans dapat dipaparkan sebagai berikut:

"Rata-rata pendapatan yang mereka terima dari hasil penjualan kelapa sawit saat ini adalah sekitar Rp 400.000 per bulan. Pendapatan yang mereka terima ini jelas tidak mencukupi untuk memenuhi kebutuhan keluarga selama satu bulan. Apalagi jika keluarga tersebut mempunyai anak banyak (lebih dari 4 orang) bisa jadi pendapatan yang diterimanya akan menjadi minus".

Gambaran orang miskin serta strategi nafkah yang dilakukan rumahtangga petani dalam masyarakat petani plasma kelapa sawit dapat diilustrasikan sebagai berikut:

\footnotetext{
${ }^{29}$ pada saat krisis moneter banyak petani yang merasa beruntung sehingga mampu membeli sepeda motor dan bisa pulang kampung
} 
"Umumnya para petani mencari kerja tambahan selain berkebun kelapa sawit. Hal ini dilakukan karena untuk memenuhi kekurangan kebutuhan per bulannya. Usaha atau pekerjaan sampingan yang sering dilakukan adalah menjadi buruh di kebun (nunas, panen, nebas dll). Selain itu ada juga yang berusaha mencari kayu di hutan untuk dibuat menjadi papan dan ada pula yang bekerja sebagai sopir, menjual tempe dan sebagainya. Bahkan ada juga yang berhutang terlebih dahulu ke KUD untuk membeli sembako atau ke warungwarung sekitar rumah mereka. Selain itu para ibu juga sering membantu untuk memecahkan persoalan kekurangan dana ini. Umumnya kaum wanita bekerja membuat dan menjual tempe atau jika di kebun kerjanya mengumpulkan kelapa sawit yang sudah jatuh (mbrondol). Sedangkan menjual kapling kebun dan pergi atau ikut transmigrasi lagi merupakan upaya yang paling akhir untuk memenuhi kebutuhan sehari-hari. Sebisa mungkin hal ini tidak akan dilakukan.

Kondisi kekurangan dana untuk keluarga ini akan semakin parah jika sakit. Bila badan sakit maka tidak dapat mengerjakan apa-apa, seperti mencari pekerjaan tambahan. Padahal jika bisa mencari pekerjaan akan terasa lebih enak. Namun jika jatuh sakit itu merupakan hal tidak diinginkan. Apalagi dengan kondisi pengobatan yang saat ini semakin mahal. Berobat sakit kepala atau perut, jika dikenai biaya sebesar Rp 30.000 30 , sudah dianggap murah, dan yang sering terjadi adalah lebih dari itu. Bagi wong cilik yang mempunyai ekonomi lemah fenomenanya adalah jika orang lain masih bisa membeli beras, maka kita tidak bisa dan sulit untuk memenuhi permintaan jajan anak-anak.

Meskipun wong cilik ini mempunyai berbagai pekerjaan sampingan yang juga menghasilkan uang, namun kebun kelapa sawit masih dianggapnya sebagai usaha yang pokok dan lebih enak, karena usaha ini sifatnya menetap, seperti menerima gaji setiap bulannya”. (lampiran 2)

Kondisi dan dinamika kesejahteraan ekonomi petani pada beragam lapisan di Perkebunan Rakyat di Provinsi Riau selama tiga tahun pasca krisis menunjukan kecenderungan merosotnya kesejahteraan ekonomi, yang tampak lebih kuat pada Perkebunan Rakyat Kelapa Dalam (di wilayah Indragiri Hilir) dibanding Perkebunan Rakyat PIR Trans (di wilayah Kampar). Strategi nafkah ganda rumahtangga dalam upaya peningkatan kembali kesejahteraan ekonomi petani beragam lapisan di Perkebunan Rakyat, perlu ditempatkan dalam kerangka multilevel (beragam tingkatan) lokal, baik di tingkat rumahtangga petani maupun di tingkat komunitas dan pemerintah lokal. Di tingkat rumahtangga petani, strategi adaptasi dalam bentuk pengembangan strategi nafkah ganda rumahtangga dilakukan melalui:

\footnotetext{
${ }^{30}$ Masyarakat setempat menyebut upah berobat ini dengan istilah tigang ndoso mawon. Karena setiap berobat, apa pun sakitnya kepada mantri kesehatan (paramedis) paling murah ongkosnya Rp 30.000,-
} 
Tabel 1. Pola Strategi Adaptasi di Dua Studi

\begin{tabular}{|c|c|c|c|c|c|}
\hline \multirow{3}{*}{\multicolumn{2}{|c|}{ Strategi Adaptasi }} & \multicolumn{4}{|c|}{ Provinsi Riau } \\
\hline & & \multicolumn{2}{|c|}{ Indragiri Hilir } & \multicolumn{2}{|c|}{ Kampar } \\
\hline & & Lapisan Atas & Lapisan Bawah & Lapisan Atas & Lapisan Bawah \\
\hline 1. & $\begin{array}{l}\text { Optimalisasi tenaga } \\
\text { kerja: pola nafkah } \\
\text { ganda }\end{array}$ & $\begin{array}{l}\text { Diversifikasi } \\
\text { nafkah dalam } \\
\text { rangka } \\
\text { akumulasi modal }\end{array}$ & $\begin{array}{l}\text { Beragam pekerjaan } \\
\text { (nelayan, peladang, } \\
\text { buruh) untuk } \\
\text { bertahan hidup }\end{array}$ & $\begin{array}{l}\text { Diversifikasi } \\
\text { nafkah dalam } \\
\text { rangka } \\
\text { akumulasi modal }\end{array}$ & $\begin{array}{l}\text { Beragam pekerjaan } \\
\text { (mencari kayu di } \\
\text { hutan, ladang, buruh } \\
\text { kebun) untuk } \\
\text { bertahan hidup }\end{array}$ \\
\hline & $\begin{array}{l}\text { Pengembangan } \\
\text { jaringan dan } \\
\text { partisipasi } \\
\text { kelembagaan }\end{array}$ & $\begin{array}{l}\text { Menanam modal } \\
\text { di tauke }\end{array}$ & $\begin{array}{l}\text { Memperkuat } \\
\text { hubungan patron- } \\
\text { client dengan tauke; } \\
\text { mencari patron } \\
\text { baru }\end{array}$ & $\begin{array}{l}\text { Memperkuat } \\
\text { hubungan dalam } \\
\text { kelompok tani }\end{array}$ & $\begin{array}{l}\text { Memperkuat } \\
\text { hubungan } \\
\text { kontraktual dengan } \\
\text { petani pemilik } \\
\text { (majikan) }\end{array}$ \\
\hline
\end{tabular}

Strategi adaptasi petani beragam lapisan (strategi nafkah ganda rumahtangga dan pengembangan jaringan) dalam mengatasi kemiskinan merupakan tindakan yang tepat, sesuai dengan lingkungan cultural, sosial, politik, ekonomi dan ekologi dimana mereka hidup. Strategi yang diterapkan tersebut didasarkan pada kepentingan ekonomi maupun sosial, yaitu pada tindakan untuk penciptaan peluang usaha dan kerja serta penanggulangan resiko usaha. Oleh karena itu, strategi yang dilakukan di tingkat rumahtangga petani dalam upaya penanggulangan kemiskinan perlu didukung melalui pengembangan kapasitas komunitas atau masyarakat setempat serta dukungan program penanggulangan kemiskinan yuang berorientasi pada pengembangan program yang disusun sesuai kebutuhan golongan miskin itu sendiri. Pengembangan kapasistas komunitas mencakup identifikasi: (1). Siapa saja pemimpin atau tokoh masyarakat yang mampu menggerakkan petani beragam lapisan; (2). Dimana saja sumber dana di tingkat komunitas yuang mampu dimanfaatkan; (3). Kelembagaan lokal apa saja yang berperan dalam penanggulangan kemiskinan; (4). Strategi pengembangan jaringan.

\section{Kesimpulan}

Pengelolaan perkebunan rakyat relatif dapat meningkatkan kesejahteraan ekonomi masyarakat. Namun dalam tiga tahun terakhir pasca krisis kondisinya relatif menurun karena memburuknya/anjloknya harga komoditas perkebunan (kelapa dalam dan kelapa sawit). Dinamika pengelolaan perkebunan rakyat semakin mengarah pada ketidakberdayaan komunitas petani kelapa dan ketergantungan pada kekuatan luar (monopoli pabrik minyak kelapa) serta menghasilkan kemiskinan petani.

Interaksi antara kelembagaan ekonomi lokal (patronase dan KUD) dan kelembagaan intervensi pasar telah membawa perubahan pada tatanan kelembagaan ekonomi lokal, dimana etika subsistensi masih menjadi tuntutan moral, namun tidak memberi peluang bagi petani untuk meningkatkan kesejahteraan. Bahkan bekerjanya mekanisme kelembagaan pasar selama krisis ekonomi telah meningkatkan kesenjangan antar lapisan. 
Kelembagaan ekonomi lokal belum sepenuhnya efektif dalam mengelola perkebunan rakyat secara berkelanjutan, maupun dalam meningkatkan kesejahteraan dan pemberdayaan petani. Upaya penguatan kelembagaan ekonomi lokal dalam rangka pemberdayaan petani kelapa dengan demikian perlu meredefinisi ulang atau menciptakan tata nilai etika subsistensi tidak hanya sebagai asuransi sosial, tetapi juga sebagai asuransi kesejahteraan bagi petani dengan memberi akses pada penguasaan asset/modal. Tindakan ekonomi ini perlu didorong dalam rangka keamanan berinvestasi jangka panjang.

Dimensi kepentingan ekonomi maupun sosial yaitu pada wujud tindakan penciptaan peluang usaha/kerja, peningkatan kapabilitas dan penanggulangan resiko usaha/kerja. mendasari perilaku petani beragam lapisan dalam upaya mengatasi kemiskinan dan meningkatkan taraf hidupnya. Strategi nafkah ganda rumahtangga yang dilakukan petani kaya adalah melalui pengembangan ragam nafkah dengan menggunakan tenaga kerja dalam rangka akumulasi modal serta pengembangan partisipasi kelembagaan, sedangkan pada petani miskin cenderung survival (bertahan hidup). Strategi ini sesuai dengan kondisi sosial budaya, struktur sosial dan sumberdaya alam komunitas petani pekebun.

\section{Daftar Pustaka}

Burns, Tom R., Baumgartner, Thoimasl; dan Devilie, Philippe. 1987. Manusia, Keputusan, Masyarakat. Teori Dinamika Antara Aktor dan Sistem untuk Ilmu Sosial. PT. Pradnya Paramita, Jakarta.

Etzioni, Amitai. 1992. Dimensi Moral. Menuju Ilmu Ekonomi Baru. Penerbit PT Remaja Rosdakarya, Bandung.

Granovetter, Mark and Swedberg, Richard. 1992. The Sociology of Economic Life. Westview Press, Inc.

Quibria M.G. 1996. Rural Poverty in Developing Asia. Asian Development Bank

Swedberg, Richard. 1998. Max Weber and the Idea of Economic Sociology. Princeton University Press. New Jersey, US.

Swedberg, Richard. 2003. Principles of Economic Sociology. Princeton University Press. New Jersey, US.

Scott, J.C. 1989. Moral Ekonomi Petani: Pergolakan dan Subsistensi di Asia Tenggara. LP3ES, Jakarta.

Sumarti, Titik dan Rudi Irawan. 2000. Laporan Sosiologi Studi Produksi Perkebunan Rakyat dan Penanggulangan Kemiskinan. Provinsi Riau. Pusat Penelitian dan Pengembangan Perkebunan bekerjasama dengan World Bank. (tidak diterbitkan)

Uphoff, Norman T. 1986. Local Institutional Development: An Analytical Source Book With Cases. Kumarian Press, Connectitut. 